\title{
How Discipline Mediates the Relationship between Additional Income and Employee Performance
}

\author{
Adhe Wulan Ernaningtyas ${ }^{1}$, Wiyarni Wiyarni ${ }^{2}$, Lidia Andiani ${ }^{3}$ \\ 1,2,3 Post Graduate STIE Malangkucecwara Malang, East Java, Indonesia
}

\begin{abstract}
This study aims to examine the effect of additional income on employee performance mediated by employee discipline in the Regional Secretariat of Pasuruan District. Number of respondents used in this study is as many as 50 respondents; all respondents were employees in the Regional Secretariat of Pasuruan District. The data in this study were obtained from the results of filling out the questionnaire. The data were analyzed using the Partial Least Square (PLS) technique with the help of the Smart PLs program. This study found that additional income has a positive and significant effect on performance, this indicates that the better the additional income, the better the employee's performance, and vice versa. The results of further analysis show that additional income has a positive and significant effect on discipline, this shows that the better the employee discipline, the better the employee's performance, and vice versa. The results of this study also indicate that discipline has a positive and significant effect on performance, this indicates that the higher the work discipline of employees, the better the employee's performance, and vice versa. In the mediation test, it is concluded that discipline can mediate the indirect effect of additional income on performance. Additional income in accordance with employee expectations will improve employee work discipline which in turn will improve employee performance.
\end{abstract}

Key words: additional income, discipline, employee performance, partial least square

\section{Background}

State Civil Apparatuses abbreviated ASN are Indonesian citizens who fulfill certain requirements. They are appointed permanently by civil development officials to occupy government positions (Law. RI No. 5 of 2014 concerning State Civil Apparatuses). The implementation of good governance can be realized by a system and apparatus that has good performance (Yusfa, 2017). The performance of government officials in most areas of government is still in the spotlight of various parties to date. The payroll system for ASN in Indonesia is still an important issue related to the welfare of life. Salaries received must truly guarantee the life of employees properly, both when they are still actively working until when they retire later. The current payroll system in Indonesia generally uses a base on rank and tenure. ASN of the same rank are given the same salary plus benefits to employees who carry out certain jobs that are continuous, meaning that payroll is given without regard to the load of work responsibilities. For every bureaucracy, salary is a cost incurred in return for employee contributions in achieving bureaucratic goals. The ASN payroll system is paid according to workload, responsibilities, and work risks (Law Number 5 of 2014 concerning State Civil Apparatus).The basic salary is expected to make life prosperous and stimulate the enthusiasm of ASN. It is stated in Law Number 5 of 2014 concerning State Civil Apparatus Article 79 paragraph (1) The government is required to pay a fair and proper salary to civil servants and guarantee the welfare of ASN; Paragraph (2) The salary as referred to in paragraph (1) is paid according to the workload, responsibilities and risks of the work. Based on the article in the Law above, it can be concluded that the payroll system needs to be carried out fairly based on the workload and responsibility of employees in order to be an incentive for the bureaucracy to work effectively. Salary and welfare will affect the morale and performance of ASN, resulting in a decrease or increase in the performance of ASN in carrying out their main duties and functions. There are many factors that can affect the performance of ASN, one of them is work discipline. Work discipline is a concept in an organization or management to require its members to behave according to rules. Discipline is a condition that causes or gives encouragement to employees to do all activities in accordance with established norms or rules. In other words making employee discipline is a form of training that seeks to improve and shape employee knowledge, attitudes, and behavior so that these employees voluntarily try to work cooperatively with other employees and improve their work performance (Handoko, 2003).

In order to increase the employee performance and discipline of State Civil Apparatuses (ASN), government gives additional income. This additional income is regulated by Pasuruan District Regulation Number 5 of 2018 concerning Additional 


\section{How Discipline Mediates the Relationship between Additional Income and Employee Performance}

Income of ASN in the Government of Pasuruan District in 2019.Based on the explanation above, the purpose of this study is to examine the role of work discipline in mediating the relationship between additional income and the performance of ASN in Regional Secretariat of Pasuruan District.

\section{Employee Performance}

One of the strategic position that can be used an organization to improve its productivity is qualified human resources. The qualified human resources in the company can be seen from the employee performance. Measuring the employee performance is very important because it describes the successful of the company. Rivai (2010) states that performance is the overall outcome of a person during certain periods of duty compared with the standard of the work, the targets or criteria that have been determined by the organization. More detail Rivai (2010) states that performance is influenced by job satisfaction, compensation, skills, abilities and individual traits. It can be concluded that employee performance is determined by the ability, desire and environment. Employee performance is also influenced by various characteristics of each person. The performance of government agencies can be described in a description of achievement level. The vision, mission, and strategy of government agencies identify the level of success and failure in implementation their programs and policies (Supriyan to, 2009: 239).Performance measurement can be defined as a process to evaluate the progress of work towards predetermined goals and objectives (Robertson, 2009: 25). Performance measurement is a management tool to improve the quality of decision making and accountability (Whittaker, 2009). Performance measurement can also be used to evaluate the achievement of goals and objectives. There are five elements to identify and measure employee performance, namely: quality of results, quantity of results, timeliness of results, presence, and ability to work together (Mathis and Jackson, 2012).

\section{Additional Income}

Additional income, known as incentives, is a means of motivation that encourages employees to work at their optimal capacity .Additional income can be defined as extra income beyond a predetermined salary. Many companies use incentive system to motivate and reward their employees. 65 percent of companies in Finland have introduced a new rewarding system during the last three years and 50 percent of them have planned to adopt incentive system during the next three years (Salimäki, Sweins, Heiskanen \& Laamanen 2009, p.6). There is a positive relationship between incentive and productivity and beneficial to the returns of a participative employee in organization (Zwick, 2004). According to Hasibuan (2013: 118), incentives are additional remuneration given to certain employees whose performance is above standard performance. It can be concluded that additional income can be defined as an incentive or part of incentive. Indicators for providing incentives are not only based on the performance produced by employees but also be based on time worked, years of service, and must pay attention to the level of needs of employees so that these incentives can be successful and encourage employee in producing good performance.

\section{Discipline}

Discipline can be defines as an attitude and behavior to obey the organizational regulations based on self-awareness to adjust with organizational regulations. Discipline a procedure which corrects or punishes employees for violating rules or procedures (Simamora, 2004). According to Rivai (2010), discipline is a tool used by managers to communicate with their employees, so that they are willing to change their behavior. Discipline also can be described as an effort to increase awareness and willingness of employee to obey company regulations and social norms. Work discipline is a real practice of the regulations contained in an organization by employees. Discipline is not only in the form of obedience but also the responsibility given by the organization. Indicators of discipline used in this research are adopted from Hasibuan (2010). Those indicators consist of attitudes, norms, and responsibilities. Attitude employee behavior that comes from the awareness or willingness of himself/herself in carrying out the tasks and regulations of the company. Normsare rules about what should and should not be done by employees in the company and as a reference in attitude. Responsibility is the ability to carry out tasks and regulations of the company. Completing job at a specified time means that employees have to be responsible for the work by completing work on time.

\section{Research Framework}

Figure 1. below is the research framework of this study.

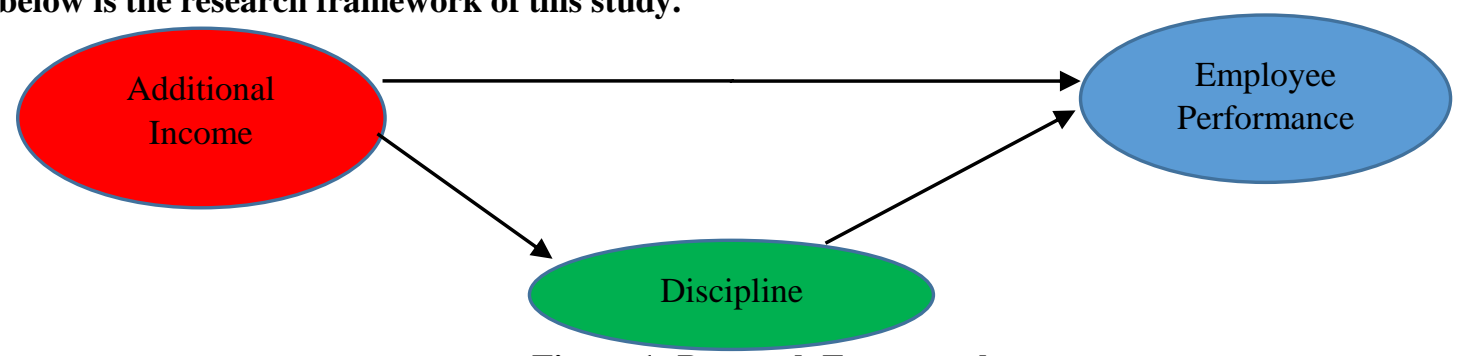

Figure 1: Research Framework 


\section{How Discipline Mediates the Relationship between Additional Income and Employee Performance}

\section{Research Hypothesis}

Based on the research framework above, the hypothesis of this study are:

H1: There is a significant influence of additional income on employee performance

$\mathrm{H} 2$ : There is a significant influence of additional income on discipline

H3: There is a significant influence of discipline on employee performance

$\mathrm{H} 4$ : There is a significant influence of additional income on employee performance with discipline as mediating variable

\section{Research Method}

This study uses quantitative approach with survey method. The population of this research is State Civil Apparatuses (ASN) in Regional Secretariat of Pasuruan District, East Java, Indonesia, which is 100 employees. The sample of this study is 50 employees which is calculated using Slow in formula. This study investigates three variables: additional income, discipline, and employee performance. Additional income has five indicators (performance, length of working, years of work, needs, and fairness and worthiness). The indicators of discipline are obey the rules of time, obey the organization rules, obey the rules of conduct at work, and obey other regulations in an organization. There are four indicators for employee performance which consist of quality of work, quantity of work, conducting of work, and responsibility. This study uses software Smart PLS version 3 for analyzing the data. The data of this study are tested for validity, reliability, structural model, and hypotheses.

\section{Results and Discussions}

Before testing the hypotheses, this study test the measurement model that includes Convergent Validity, discriminant Validity and Composite Reliability. The results of the measurement model can be used to test the research hypothesis if all indicators in the PLS model have met the requirements of convergent validity, discriminant validity and composite reliability. Convergent validity test can be seen at the loading factor value of each indicator against the construct. For confirmatory research, the loading factor limit used is 0.7 , while for exploratory research the loading factor limit used is 0.6 and for development research, the loading factor limit used is 0.5 . Because this study is a confirmatory study, the loading factor limit used is 0.7 .The results of the loading factors of each indicator can be seen in he figure 1

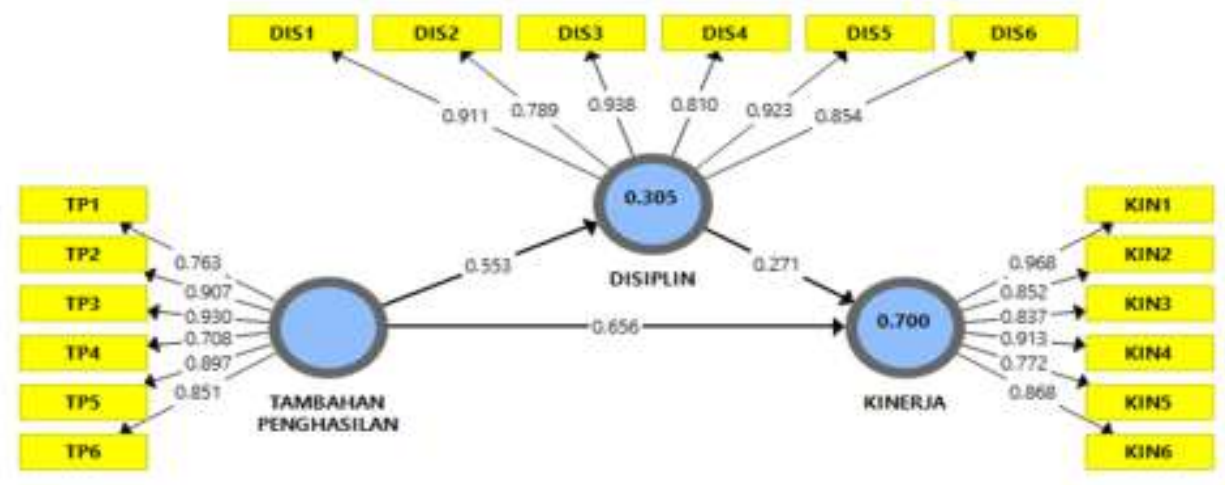

Figure 2: The Value of Loading Factor

Note:

- Tambahan penghasilan: Additional Income

- Disiplin: Discipline

- Kinerja: Employee Performance

Based on the estimation results of the PLS model in the figure 1, all indicators have a loading factor value above 0.7 so that the model has met the convergent validity requirements. Apart from looking at the loading factor value of each indicator, the convergent validity is also assessed from the AVE value of each construct, the PLS model is declared to have met the convergent validity if the AVE value of each construct is higher than 0.5. The complete AVE value of each construct can be seen in the table below:

Table 1L: The Value of Loading Factors and AVE

\begin{tabular}{|l|l|l|l|l|}
\hline Variable & Indicator & Loading Factor & AVE & Validity \\
\hline \multirow{4}{*}{ Discipline } & DIS1 & 0.911 & & valid \\
\cline { 2 - 3 } & DIS2 & 0.789 & \multirow{3}{*}{0.762} & valid \\
\cline { 2 - 3 } & DIS3 & 0.938 & & valid \\
\cline { 2 - 3 } & DIS4 & 0.810 & valid \\
\hline
\end{tabular}


How Discipline Mediates the Relationship between Additional Income and Employee Performance

\begin{tabular}{|c|c|c|c|c|}
\hline & DIS5 & 0.923 & & valid \\
\hline & DIS6 & 0.854 & & valid \\
\hline \multirow{6}{*}{ Performance } & KIN1 & 0.968 & \multirow{6}{*}{0.758} & valid \\
\hline & KIN2 & 0.852 & & valid \\
\hline & KIN3 & 0.837 & & valid \\
\hline & KIN4 & 0.913 & & valid \\
\hline & KIN5 & 0.772 & & valid \\
\hline & KIN6 & 0.868 & & valid \\
\hline \multirow{6}{*}{$\begin{array}{l}\text { Additional } \\
\text { Income }\end{array}$} & TP1 & 0.763 & \multirow{6}{*}{0.716} & valid \\
\hline & TP2 & 0.907 & & valid \\
\hline & TP3 & 0.930 & & valid \\
\hline & TP4 & 0.708 & & valid \\
\hline & TP5 & 0.897 & & valid \\
\hline & TP6 & 0.851 & & valid \\
\hline
\end{tabular}

Source: Smart PLS results

Based on the results of the PLS analysis in the table above, the AVE value of all constructs, both dimensions and variables, has exceeded 0.5 which indicates that all indicators in each construct have met the required convergent validity criteria. Discriminant validity test is done to ensure that each concept of a latent variable is different from other variables. The model has good discriminant validity if the AVE square value of each exogenous construct (the value on the diagonal) exceeds the correlation between that construct and other constructs (values below the diagonal). The results of discriminant validity testing can be seen in the table 2 below.

Table 2: Discriminant validity value

\begin{tabular}{|l|l|l|l|}
\hline & Discipline & Performance & $\begin{array}{l}\text { Additional } \\
\text { Income }\end{array}$ \\
\hline Discipline & 0.873 & & \\
\hline Performance & 0.633 & 0.870 & \\
\hline Additional Income & 0.553 & 0.806 & 0.846 \\
\hline
\end{tabular}

Source: Smart PLS results

The results of the discriminant validity test in the table above show that all constructs have a square root value of AVE above the correlation value with other latent constructs so that it can be concluded that the model has met the discriminant validity. The validity of the discriminant can also be assessed from the cross loading value of the indicator on the construct. The cross loading value of the indicator on its construct must exceed the cross loading value of the indicator against other constructs. Table 3 below shows the cross loading of indicators on the construct.

Table 3: Cross Loading

\begin{tabular}{|l|l|l|l|}
\hline Cross lading & Discipline & Performance & Additional Income \\
\hline DIS1 & $\mathbf{0 . 9 1 1}$ & 0.652 & 0.640 \\
\hline DIS2 & $\mathbf{0 . 7 8 9}$ & 0.458 & 0.398 \\
\hline DIS3 & $\mathbf{0 . 9 3 8}$ & 0.546 & 0.421 \\
\hline DIS4 & $\mathbf{0 . 8 1 0}$ & 0.588 & 0.382 \\
\hline DIS5 & $\mathbf{0 . 9 2 3}$ & 0.519 & 0.497 \\
\hline DIS6 & $\mathbf{0 . 8 5 4}$ & 0.520 & 0.501 \\
\hline Perform1 & 0.624 & $\mathbf{0 . 9 6 8}$ & 0.772 \\
\hline Perform2 & 0.421 & $\mathbf{0 . 8 5 2}$ & 0.647 \\
\hline Perform3 & 0.479 & $\mathbf{0 . 8 3 7}$ & 0.650 \\
\hline Perform4 & 0.624 & $\mathbf{0 . 9 1 3}$ & 0.738 \\
\hline
\end{tabular}


How Discipline Mediates the Relationship between Additional Income and Employee Performance

\begin{tabular}{|l|l|l|l|} 
Perform5 & 0.496 & $\mathbf{0 . 7 7 2}$ & 0.558 \\
\hline Perform6 & 0.624 & $\mathbf{0 . 8 6 8}$ & 0.801 \\
\hline Al1 & 0.455 & 0.673 & $\mathbf{0 . 7 6 3}$ \\
\hline Al2 & 0.456 & 0.720 & $\mathbf{0 . 9 0 7}$ \\
\hline Al3 & 0.455 & 0.720 & $\mathbf{0 . 9 3 0}$ \\
\hline Al4 & 0.362 & 0.492 & $\mathbf{0 . 7 0 8}$ \\
\hline Al5 & 0.334 & 0.706 & $\mathbf{0 . 8 9 7}$ \\
\hline Al6 & 0.676 & 0.734 & $\mathbf{0 . 8 5 1}$ \\
\hline
\end{tabular}

Source: Smart PLS results

Based on the table above, loading value of all indicators of discipline are higher than loading value of all indicators of performance and additional income. It is also for loading factor value of indicators of performance are higher than that value of discipline and additional income. Same results for loading factor of additional income indicators are higher than that of discipline and performance.

The reliability of the constructs can be assessed from the Cronbachs Alpha value and the Composite Reliability value of each construct. The recommended composite reliability and Cronbachs alpha value is more than 0.7 . Table 4 below shows the result of the composite reliability.

Table 4: Composite Reliability

\begin{tabular}{|l|l|l|l|l|}
\hline & $\begin{array}{l}\text { Cronbach's } \\
\text { Alpha }\end{array}$ & rho_A & $\begin{array}{l}\text { Composite } \\
\text { Reliability }\end{array}$ & $\begin{array}{l}\text { Average Variance } \\
\text { Extracted (AVE) }\end{array}$ \\
\hline Discipline & 0.937 & 0.948 & 0.950 & 0.762 \\
\hline Performance & 0.935 & 0.945 & 0.949 & 0.758 \\
\hline Additional Income & 0.919 & 0.930 & 0.938 & 0.716 \\
\hline
\end{tabular}

Source: Smart PLS results

The reliability test results in the table above show that all constructs have a composite reliability value of $>0.7$ and Cronbachs alpha> 0.7 , which indicates that all constructs have met the required reliability. After fulfilling the validity and reliability of the construct at the testing stage of the outer model, the test is continued to testing the Goodness of fit model. The fit of the PLS model can be seen from the SRMR model value. The PLS model is declared to have met the goodness of fit model criteria if the SRMR value is $<0.10$ and the model is declared perfect fit if the SRMR value is $<0.08$. The result of the goodness of fit model this study can be seen in the table 5 below.

Table 5: The goodness of fit model

\begin{tabular}{|l|l|l|}
\hline & Saturated Model & Estimated Model \\
\hline SRMR & 0.087 & 0.087 \\
\hline
\end{tabular}

The results of the PLS model goodness of fit test in the following table above shows that the SRMR value of the model in the saturated model is 0.087 and the estimated model is 0.087 . Because the SRMR value of both the saturated model and the estimated model is below 0.10, the model is declared perfect fit and feasible to use to test the research hypothesis. For hypotheses testing, it can be used the inner model test. Inner model testing includes the direct effect significance test, indirect effect testing and measurement of the influence of each exogenous variable on the endogenous variable. All of these tests will be used to test the research hypothesis. Because the research hypothesis is a one-way hypothesis, the exogenous variables have a significant effect on endogenous variables if the $\mathrm{P}$ value $<0.05$ and $\mathrm{t}$ count $>1.68$. According the results of the significance test, it can also be seen the direction of the relationship between the influence of exogenous and endogenous variables. The direction of the relationship can be seen from the original sample value of each effect relationship. If the direction of the relationship of influence is positive, then the effect of exogenous variables on endogenous is positive / unidirectional, while if the original sample value is negative, the direction of the relationship between the influence of exogenous variables on endogenous variables is opposite. The results of the model estimation as a reference for testing the hypothesis in this study can be seen in the following figure: 


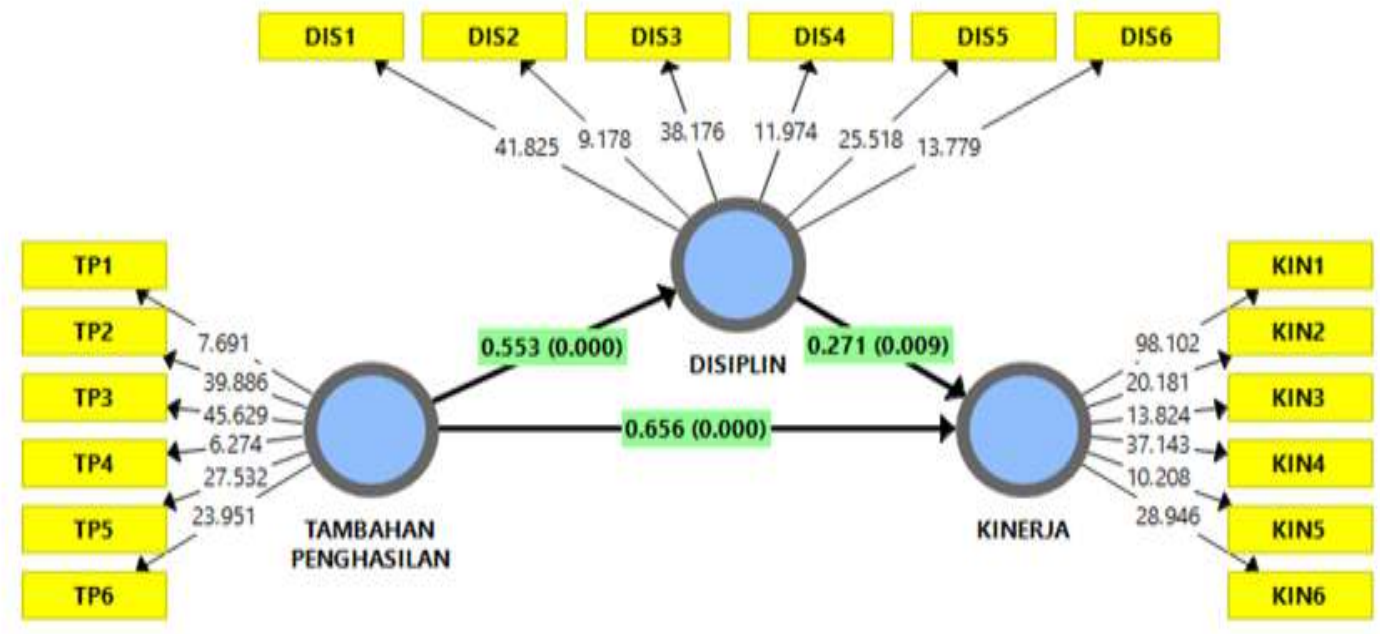

Figure 3: Estimated Model

Based on the estimation results of the PLS model using the bootstrapping technique above, all lines have a p value $<0.05$. The full significance test results of this direct effect can be seen in the following table:

Table 6: Direct Effects

\begin{tabular}{|l|l|l|l|l|l|}
\hline & $\begin{array}{l}\text { Original } \\
\text { Sample (O) }\end{array}$ & $\begin{array}{l}\text { Sample } \\
\text { Mean (M) }\end{array}$ & $\begin{array}{l}\text { Standard } \\
\text { Deviation } \\
(\text { STDEV) }\end{array}$ & $\begin{array}{l}\text { T Statistics } \\
(|\mathrm{O} / \mathrm{STDEV}|)\end{array}$ & P Values \\
\hline DIS ->Perform & 0.271 & 0.270 & 0.104 & 2.606 & 0.009 \\
\hline Al -> DIS & 0.553 & 0.547 & 0.100 & 5.512 & 0.000 \\
\hline Al ->Perform & 0.656 & 0.653 & 0.101 & 6.497 & 0.000 \\
\hline
\end{tabular}

Source: Smart PLS results

Based on the results of testing the hypothesis above, it can be explained that first, the p value of the effect of additional income on performance (AI $\rightarrow$ Perform) is 0,000 with a T statistic of 6.497 and the path coefficient is positive at 0.656 . Because the $p$ value $<0.05$, $\mathrm{T}$ statistic $>1.68$ and the positive path coefficient, it can be concluded that additional income has a positive and significant effect on performance, this indicates that the better the additional income, the better employee performance, and vice versa. Based on the value of the path coefficient that connects the two variables, it can be seen that $65.6 \%$ of the variance in employee performance is influenced by additional income variables. Second, the $\mathrm{p}$ value of the effect of additional income on discipline (AI $\rightarrow$ DIS) is 0.000 with a $\mathrm{T}$ statistic of 5.512 and the path coefficient is positive at 0.553 . Because the $\mathrm{p}$ value $<0.05, \mathrm{~T}$ statistic $>1.68$ and the positive path coefficient, it can be concluded that additional income has a positive and significant effect on discipline, this indicates that the better employee discipline, the better employee performance, and vice versa. Based on the path coefficient value that connects the two variables, it can be seen that $55.3 \%$ of the variance in employee performance is influenced by employee discipline. Third, $p$ value of the effect of discipline on performance (DIS $\rightarrow$ Perform) is 0.009 with a T statistic of 2.606 and the path coefficient is positive at 0.271 . Because the $\mathrm{p}$ value $<0.05$, $\mathrm{T}$ statistic $>1.68$ and the positive path coefficient, it can be concluded that discipline has a positive and significant effect on performance, this indicates that the higher the employee work discipline, the better the employee's performance, and vice versa. Based on the path coefficient value that connects the two variables, it can be seen that $27.1 \%$ of the variance in employee performance is influenced by employee work discipline. In this study, the discipline variable is a mediating variable that mediates the indirect effect of additional income on performance. The result of the test of the significance of the indirect effect of additional income variables on performance mediated by work discipline, can be shown in the table 7 below.

Table 7: Test of indirect effect

\begin{tabular}{|l|l|l|l|l|l|}
\hline & $\begin{array}{l}\text { Original } \\
\text { Sample (O) }\end{array}$ & Sample Mean (M) & $\begin{array}{l}\text { Standard Deviation } \\
\text { (STDEV) }\end{array}$ & $\begin{array}{l}\text { T Statistics } \\
(\mid \text { O/STDEV } \mid)\end{array}$ & P Values \\
\hline Al -> DIS ->Perform & 0.150 & 0.148 & 0.065 & 2.317 & 0.021 \\
\hline
\end{tabular}

Source: Smart PLS results

Based on the results of testing the indirect effect in the table above, p value is 0.021 , because the $\mathrm{p}$ value obtained is $<0.05$, it can be concluded that the discipline variable can mediate the indirect effect of additional income on performance. Additional income in 


\section{How Discipline Mediates the Relationship between Additional Income and Employee Performance}

accordance with employee expectations will improve employee work discipline which in turn will improve employee performance. This study also analyze how strength the independence variables influence the dependent variables. $R$-Square $\left(R^{2}\right)$ can show the strength and weakness of the influence of independent variable on the dependent variable. R-Square $\left(R^{2}\right)$ can also show the strength and weakness of a research model. According to Chin, (1995) the R-Square $\left(\mathrm{R}^{2}\right)$ value of 0.67 is classified as a strong model, $\mathrm{R}$ Square $\left(R^{2}\right)$ of 0.33 is a moderate model, and an $R$-Square $\left(R^{2}\right)$ of 0.19 is classified as a weak model. The $R^{2}$ of this study can be seen in the table 8 below.

Table 8: The value of $R-S q u a r e ~\left(R^{2}\right)$

\begin{tabular}{|l|l|l|}
\hline & R Square & R Square Adjusted \\
\hline Discipline & 0.305 & 0.291 \\
\hline Performance & 0.700 & 0.687 \\
\hline
\end{tabular}

Source: Smart PLS results

Based on the results of the analysis in the table above, the $\mathrm{R}$ square value of the discipline variable is 0.305 , this shows that $30.5 \%$ of employee discipline is influenced by the suitability of additional income, and the $\mathrm{R}$ square value of the performance variable is 0.700 indicating that $70 \%$ of performance variance employees are affected by the suitability of additional income and employee work discipline, while the remaining $30 \%$ of the variance in performance is influenced by other variables outside the suitability of additional income and employee work discipline. It can be concluded that the model of effect of additional income on discipline can be said moderate, and effect of additional income and discipline on performance can be said strong.

\section{Discussions}

The results of the analysis in this study indicate that additional income has a positive and significant effect on performance, this indicates that the better the additional income, the better the employee's performance, and vice versa. Based on the value of the path coefficient that connects the two variables, it can be seen that $65.6 \%$ of the variance in employee performance is influenced by additional income variables. This can be proven by the additional income it can motivate employees to give their best performance. If employee's hard work and best performance are recognized and appreciated by the organization, they will be more motivated to improve their performance. Therefore, the first hypothesis is accepted. The second hypothesis states that there is an effect of additional income on discipline. This hypothesis is proven; because the statistic results indicate that additional income has a positive and significant effect on discipline. It means that the better the employee discipline, the better the employee's performance, and vice versa. Based on the path coefficient value that connects the two variables, it can be seen that $55.3 \%$ of the variance in employee performance is influenced by employee discipline. By stipulating additional income for employees, it will have a strong influence on the mindset, behavior and work patterns of employees. This is shown by the strong desire to improve competence, to act in a broader dimension not only in time discipline. The results of the analysis in this study indicate that discipline has a positive and significant effect on performance, this indicates that the higher the work discipline of employees, the better the employee's performance, and vice versa. Based on the path coefficient value that connects the two variables, it can be seen that $27.1 \%$ of the variance in employee performance is influenced by employee work discipline. Discipline in this case is not only about time discipline, but also encourages employees to increase their competence and work more quality even in more specific areas such as being eager to serve the community. It can be concluded that the third hypothesis is accepted. The last hypothesis of this study is that the discipline mediates the relationship between additional income and performance. The results of this study indicate that the discipline variable can mediate effect of additional income on performance. Additional income in accordance with employee expectations will improve employee work discipline which in turn will improve employee performance. This means that the performance of ASN is getting better if the effect of remuneration is getting better, preceded by the creation of higher discipline that is owned by each individual.

\section{Conclusion}

Based on the results of the analysis in this study, the results of the analysis show that basically the additional income has been in accordance with the expectations of the employees, but in terms of suitability of employee positions according to their fields and abilities, it still needs to be improved. The Regional Secretariat of Pasuruan District also needs to avoid multiple roles or multiple jobs for the employees, because it will make employees less able to work in a disciplined manner and have poor performance.

\section{References}

1) Handoko, T. Hani. 2003. Manajemen Personalia dan Sumber Daya Manusia. Yogyakarta: BPFE

2) Hasibuan, Malayu S P. 2013. Manajemen Sumber Daya Manusia Perusahaan. Cetakan ke-17, Jakarta : PT. Bumi Aksara

3) Mathis, Robert L. dan Jhon H. Jackson. (2012). Manajemen Sumber Daya Manusia. Edisi Kespuluh - Jakarta : Selemba Empat. 
How Discipline Mediates the Relationship between Additional Income and Employee Performance

4) Rivai.2010. Manajemen Sumber Daya Manusia untuk Perusahaan dari Teori ke Praktik edisi Kedua.Jakarta : Rajawali Press

5) Robertson, GL. (2009). Food Packaging and Shelf Life: A Pratical Guide. CRC. Press Salimäki A., Sweins C., Heiskanen J. \&Laamanen T. 2009.

6) Palkitsemisen tila ja muutos Suomessa 2008. Helsinki University of Technology. Department of Industrial Engineering and Management. Report 2009/3

7) Simamora, Henri, 2000, Manajemen Sumber Daya Manusia, Cetakan Pertama edisi kedua, Penerbit: YKPN, YogyakartaSupriyanto Abdi. (2009).

8) Potret Pemenuhan Hak atas Pendidikan dan perumahan di era Otonomi Daerah. Yogyakarta: PUSHAM UII.Taufiq Yusfa. 2017.

9) Pengaruh Tambahan Penghasilan Pegawai, Mutasi, Motivasi, Dan Kepuasan Kerja Terhadap Prestasi Kerja, Dengan Efikasi Diri Sebagai Variabel Pemoderasi (Studi Pada Pemerintah Daerah Kota Metro). http://digilib.unila.ac.id/29356

10) Whittaker, James O. (2009). Introduction to Psychology. (London: W.B. Sounders.

11) Zwick, T. (2004). Employee participation and productivity. Labour Economics, 11, 715-740. 